\title{
NOTE DE SYNTHÈSE SUR LA SÉLECTION DE NICHE SPATIALE ET LA COMPÉTITION CHEZ LE JEUNE SAUMON ATLANTIQUE (SALMO SALAR) ET LA TRUITE COMMUNE (SALMO TRUTTA) EN MILIEU LOTIQUE.
}

\author{
J. HEGGENES (1), J.L. BAGLINIÈRE (2), R. CUNJAK (3).
}

(1) Department of Biology and Nature Conservation, Agricultural University of Norway, P.O. Box 5014, 1432 Ảs, Norway.

(2) Laboratoire d'Ecologie Hydrobiologique, INRA Centre de Recherche de Rennes, 65 rue de Saint-Brieuc, 35042 Rennes Cedex, France.

(3) Canada Department of Fisheries and Oceans, Science Branch, P.O. Box 5030, Moncton, N.B., Canada E1C 9B6.

\section{RÉSUMÉ}

La sélection de l'habitat analysée à partir d'un ensemble de données récoltées sur des cours d'eau hétérogènes du point de vue spatio-temporel doit être interprétée en fonction du site et de l'échelle d'étude. La microniche spatiale fondamentale du juvénile de saumon Atlantique et de truite commune est caractérisée en été par une forte préférence pour une faible valeur de la vitesse de courant focale en raison d'une stratégie de gain énergétique basée essentiellement sur une prise alimentaire de la faune dérivante qui permet de maximiser les comportements de prise de position et d'attente du poisson. Cette microniche est également dépendante de la taille : chez le saumon, les plus gros parrs sont tolérants ; par contre chez la truite, une préférence accrue pour les habitats profonds est observée lorsqu'elles grossissent. La niche effective de la truite est relativement plus structurée par des valeurs élevées de la profondeur d'eau et des valeurs faibles de vitesse de courant lorsqu'elle est comparée à celle du saumon caractérisée par de faibles hauteurs d'eau et par des vitesses de courant élevées. Ces différences proviennent d'une plus grande tolérance du saumon pour les fortes vitesses de courant, combinée à un déplacement de la niche de cette espèce par suite d'une compétition avec la truite qui est plus agressive. Cette compétition interactive et interspécifique aboutit à une réduction de la niche spatiale effective chez le Saumon lorsque les paramètres vitesse de courant et profondeur d'eau sont pris en compte simultanément, et pas chez la truite.

\section{SYNTHETIC NOTE ON SPATIAL NICHE SELECTION AND COMPETITION IN YOUNG ATLANTIC SALMON (SALMO SALAR) AND BROWN TROUT (SALMO TRUTTA) IN LOTIC ENVIRONMENTS.}

\section{SUMMARY}

Habitat selection data from spatio-temporally heterogeneous streams must be interpreted in the light of site and scale studied. The fundamental spatial microniche in summer in both young Atlantic salmon, Salmo salar, and brown trout, S. trutta, is characterized by strong preference for low snout water velocities, because of the principal drift-feeding strategy of energy-intake maximizing sit-and-wait. The strategy is described by a simple model. Fundamental niche is size-structured, with larger parr being more dynamically robust in salmon, whereas trout show increasingly strong preferences for pools as they grow. Realized niche in trout is deep-slow relative to salmon's swift(-shallow) niche, which is a result of greater tolerance for higher water velocities in salmon combined with competitive niche displacment in the presence of the more aggressive trout. Interspecific interference competition cause a narrower spatial niche with respect to both water velocity and depth in salmon, but not in trout. 


\section{INTRODUCTION}

Studies of spatial niche and (micro)habitat selection often focus on the importance of abiotic factors in regulating population numbers. However, biotic factors can also influence animal populations. This is particularly obvious in spatially heterogenous environments such as running waters where spatial segregation by species, body size and social hierarchy can be the result of competitive interactions. Temporal variability of the environment may further influence population regulation; directly or by interacting with biotic factors, to alter resource availability and use.

Habitat selection is generally regarded as a trade-off between potential energy intake and risk (HART, 1993), and variation in these two factors causes individual variation in survival, growth and reproductive success. Spatial heterogeneity implies an unequal availability of energy and potential risk. Therefore, within a species' generation, spatial heterogeneity is an important factor in regulating density-dependent processes in populations.

Stream-living salmonids, in particular territorial or localized dominance hierarchy species (BACHMAN, 1984), may be assumed to have evolved adaptive behavioural tactics to utilize and buffer the spatial diversity in most stream environments. Habitat selection is, therefore, likely to be an important factor in their life history strategies. A major role in the decline of stocks of wild Atlantic salmon (Salmo salar L.) has been the loss of suitable freshwater habitat (BAGLINIËRE et al., 1990). A similar hypothesis may be posed for brown trout (S. trutta L.), although extensive stocking confound the issue for this species. The two species have a similar ecology, are sympatric and interact in most streams in Europe. Thus, the quantity and quality of suitable freshwater habitat is of great importance in the ecology and management of these species. This selected review briefly summarizes results from studies on important aspects of fundamental niche, i.e. niche occupied in the absence of competitors and predators, and contrasts these results with realized spatial niche of young Atlantic salmon and brown trout. Here we emphasise the energy constraints set by water velocities resulting in a general model for microposition choice, and the importance of competitive interactions in habitat selection. Influence of environmental variability will be dealt with elsewhere (HEGGENES et al., unpubl.).

\section{SITE AND SCALE CONSIDERATIONS}

Fish are distributed between habitat patches in a nonuniform way. If a stream is sampled at random and certain environmental characteristics of patches are measured, generalized probability functions for habitat selection can be constructed through correlational analyses. Unless one hypothesizes a causal mechanism for spatial niche selection, great amounts of data are necessary to generalize trends. It is a logical problem to extrapolate such data beyond the study stream and range of habitat conditions sampled, until potential «universal» patterns are established (MORANTZ et al., 1987).

Also, questions about predictability (e.g. suitability of habitat) depend on the scale at which they are asked. In heterogeneous natural streams, designated patch size is likely to affect the form of the resulting probability functions. Furthermore, events within any one patch may be highly variable and unpredictable, while events on a larger scale may be relatively stable.

In general, two scales are adopted in stream habitat studies. A "mesohabitat" scale focuses on quantifying physical characteristics of habitat patches $\left(<50 \mathrm{~m}^{3}\right)$, and equates to "habitat-type" (e.g. a riffle or run or pool) in small streams - medium sized rivers (1st - 5th order). "Microhabitat" studies focus on stream points, i.e. the snout position of the individual fish, and usually the immediate vicinity providing additional information, i.e. patches up to $1 \mathrm{~m}^{3}$. On a third and large scale, "macrohabitat" descriptions refer to stream reaches and orders and is a product primarily of habitat observations coupled with data on geomorphology and climate (VANNOTE et al., 1980).

The aspect of temporal scale has attracted less attention than spatial scale. Most studies are done during daytime in summer and at low waterflows. However, temporally variable water flows and temperatures are pervasive environmental factors that affect behaviour and spatial niche selection in salmon and trout and other streamfishes (CUNJAK, 1988 ; HEGGENES et al., 1993 ; FRASER et al.,1994). 


\section{FUNDAMENTAL SPATIAL NICHE IN YOUNG ATLANTIC SALMON IN SUMMER}

Snout water velocity is the most consistent variable that defines the fundamental spatial niche of Atlantic salmon parr (MORANTZ et al., 1987 ; HEGGENES and SALTVEIT, 1990). Parr prefer snout velocities in the range $5-25 \mathrm{cms}^{-1}$, and select these by moving up and down in the water column or laterally within a habitat patch. The fundamental niche is size-structured with the small parr $(<7 \mathrm{~cm})$ having the more restricted niche. Apparently as a result of a specific rheotactic response, the young and small parr avoid the slowest flow areas (HEGGENES and BORGSTRØM, 1991). Probably more as a result of physical stress, all salmon parr avoid the fastest flowing $\left(>100 \mathrm{cms}^{-1}\right)$ stream areas. Parr generally avoid deep stillwater areas of > 2 m (GIBSON, 1993 ; but see HUTCHINGS, 1986).

Salmon parr also avoid stream areas with sand and mud where substrates are finer than pebbles (<16 mm) (KARLSTRØM, 1977), which also appear to be part of an specifically defined spatial niche.

\section{REALIZED SPATIAL NICHE IN YOUNG ATLANTIC SALMON IN SUMMER}

Mean (or surface) water velocites, usually in the preferred range $30-50 \mathrm{cms}^{-1}$, are often rated as the more important mesohabitat variable. These velocities are usually in combination with coarse substratum $(16-256 \mathrm{~mm})$, because these two variables are correlated (KARLSTRØM, 1977 ; BAGLINIËRE and CHAMPIGNEULLE, 1982 ; HEGGENES and SALTVEIT, 1990 ; Fig. 1). The large pectoral fins of salmon parr confer a morphological adaptation allowing greater exploitation of swift waters (JONES, 1975). However, salmon parr demonstrate flexibility with respect to preferred water velocity range, and the realized spatial niche depends on fish size, intra- and interspecific competition, and predation. During, and immediately following emergence, the small parr (or fry) are vulnerable to passive downstream displacement, depending on discharge and fish size and condition. Water depth is of relatively little importance in large rivers which abound with water depths within both suitable and tolerable ranges for salmon parr (KARLSTRØM, 1977 ; MORANTZ et al.,1987). Water depth is, however, an important factor in small streams where suitable depths are restricted (KENNEDY and STRANGE, 1986; HEGGENES, 1990), and also in estuarine (CUNJAK, 1992) and lacustrine (HUTCHINGS, 1986 ; PEPPER et al., 1992) environments. Small parr $(<7 \mathrm{~cm})$ generally use shallow areas $(<25 \mathrm{~cm})$, but widen their realized depth niche in response to reduced competition and probably also predation (KENNEDY and STRANGE, 1986).

The realized spatial niche is size structured. Larger parr $(>7 \mathrm{~cm}$ ) have a considerably wider niche in summer than small parr, and tolerate a wide range of habitat conditions, including deeper habitats $(>20 \mathrm{~cm})$, and a wide range of water velocities $\left(10-70 \mathrm{cms}^{-1}\right)$ with coarser substrates $(64-512 \mathrm{~cm})$.

\section{FUNDAMENTAL SPATIAL NICHE IN BROWN TROUT IN SUMMER}

The most consistent characteristic of spatial niche selection in brown trout is, as for young Atlantic salmon, the very narrow niche window for snout water velocity (RINCON and LOBON-CERVIA, 1993, HEGGENES unpubl.). A second consistent characteristic is that spatial niche selection in brown trout is size-structured. However, this latter characteristic appears to be the result of intraspecific competition, and thus part of the realized spatial niche.

\section{REALIZED SPATIAL NICHE IN BROWN TROUT IN SUMMER}

Small trout parr $(<7-8 \mathrm{~cm})$ are abundant in shallow, swift stream areas $(<20-30 \mathrm{~cm}$ depth, $10-50 \mathrm{cms}^{-1}$ water velocities) with cobble substrates. Larger trout have increasingly strong preferences for deep-slow stream areas, especially pools, which provide more cover. Unlike young Atlantic salmon, large brown trout have a narrower spatial niche than small parr. This is, however, a size effect. Whereas salmon parr in the lotic environment normally have a maximum size of $18-22 \mathrm{~cm}$, resident brown trout may grow to a considerably greater size $(30-60 \mathrm{~cm})$, resulting in a progressively stronger spatial niche competition and more restrictive spatial requirement (HEGGENES unpubl.). 


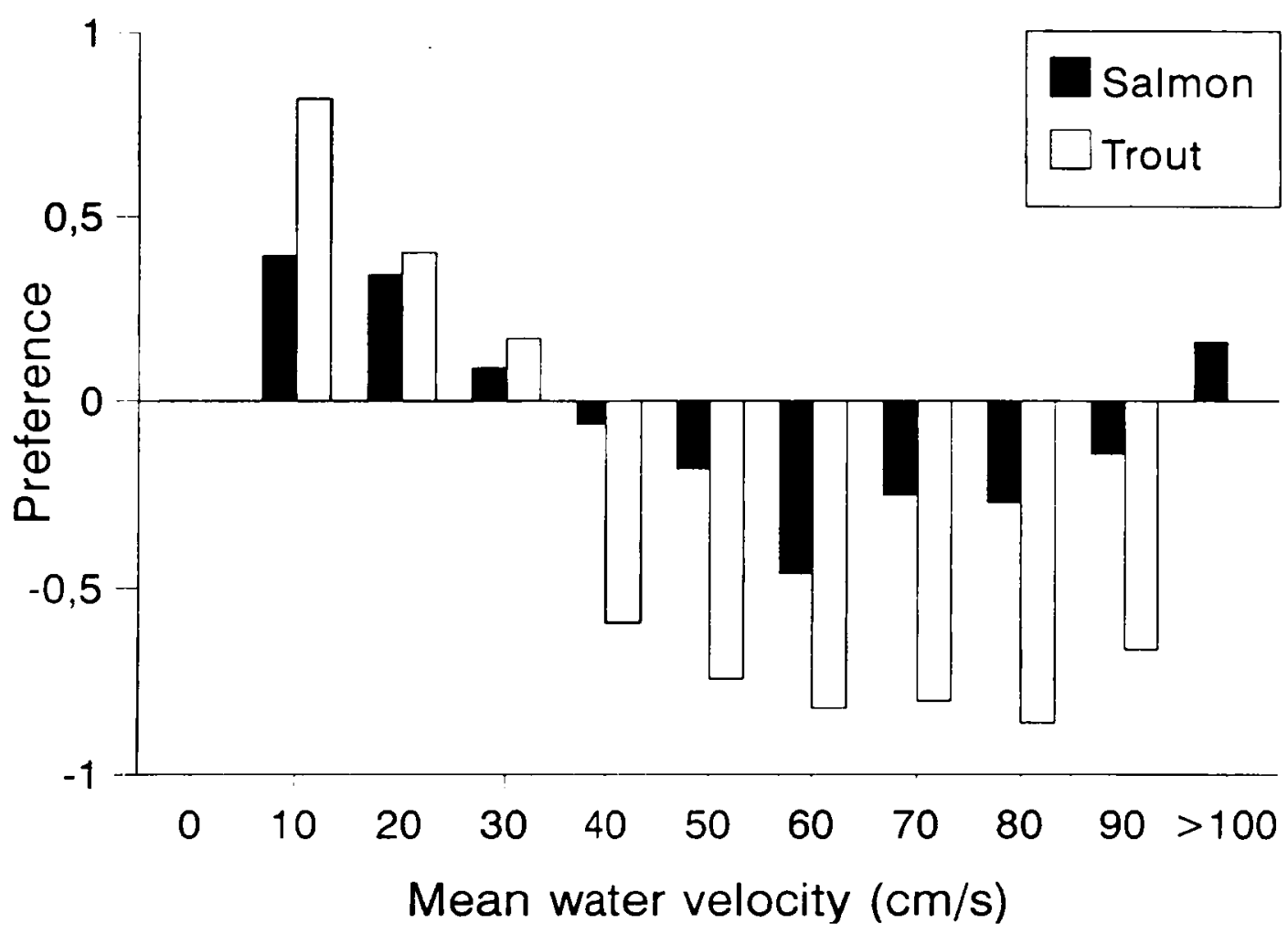

Figure 1 : Vitesses moyennes préférées par les jeunes saumons Atlantique et les jeunes truites dans un ruisseau. Les saumons sont plus tolérants que les truites, comme le montre la plus faible amplitude. Les truites évitent les zones où l'écoulement est rapide et préfèrent les mésohabitats plus lents.

Figure 1 : Mean water velocity preferences by young Atlantic salmon and trout in a stream. Salmon are more tolerant than trout, as indicated by the lower amplitude. Trout avoid fast flowing areas and prefer slower mesohabitats.

Several attempts have been made to assess the relative importance of habitat variables in habitat selection by brown trout, but there has been little consensus in distinguishing between realized and fundamental niche. Most studies rate water depth as the most important habitat variable defining spatial niche selection in brown trout, especially for larger fish and in smaller streams (KENNEDY and STRANGE, 1986 ; HEGGENES unpubl.). Other studies conclude that variables interact strongly such that no one can be singled out as more important than others (HEGGENES and SALTVEIT, 1990), or that a size-structuring effect may explain the situation for young parr, but not for the larger fish (BAGLINIERE and CHAMPIGNEULLE, 1982). Such confusion is likely the combined result of Liebigs 'law' of the minimum and Shelfords 'law' of tolerance, i.e. different variables are likely to limit populations in different streams, either through approaching the critical minimum or limits of tolerance. The emerging consensus is that depth and cover most affect the distribution of brown trout.

\section{THE GENERAL MODEL FOR MICROPOSITION CHOICE IN SUMMER}

That saimon and trout consistently and cuniversally" exhibit a narrow niche window for snout water velocities, has formed the basis for reasonably predictive models of microposition choice in salmonids under certain favourable and stable physical conditions (FAUSCH, 1984 ; HUGHES and DILL, 1990). The causal mechanism is elegantly explained 
by optimal foraging theory, i.e. microposition choice was determined by maximum net energy intake, with the focus on potential energy gain rather than risk. In streams spatial competition also substitute for direct competition for food and reduced risk (CHAPMAN, 1966), since drift-feeding is the main foraging strategy. Therefore the net energy gain potential of a holding station, i.e. both cost and gain, is determined through spatial requirements ; the single parameter of micro water velocities (HILL and GROSSMAN, 1993). Preferable positions are in low velocity micro-niches (reduced energy expenditure) close to a swift current (increased energy potential), and the fish will seek to maximize the difference between the cost and energy gain curves (Fig. 2). The principal foraging strategy in summer has been characterized as a cost-minimizing sit-and-wait strategy (BACHMAN, 1984). However, since the cost curve is rather flat while the energy potential (drift availability) curve peaks due to dramatically decreased capture success at higher velocities (HILL and GROSSMAN, 1993), the principal foraging strategy in salmonids in summer is better described as an energy intake-maximizing sit-and-wait strategy (Fig. 2).

\section{INTERSPECIFIC COMPETITIVE INTERACTIONS}

Habitat segregation may result from competitive interactions (interactive segregation; interference or exploitative competition), or from selective differences (selective segregation). Reduced amplitude or displacement of spatial niche optima and/or breadth in sympatry compared with allopatry indicate, by definition, competitive interactions. In salmonids such interactive segregation usually results from aggressive interactions together with subtle specific differences in spatial niche breadth (HEARN, 1987). Sympatric brown trout and young Atlantic salmon overlap considerably in their habitat use (HEGGENES and SALTVEIT, 1990, Fig. 1), suggesting potential interspecific competition provided that resource demand exceeds availability. Young Atlantic salmon tend, however, to be distributed more in the swift shallow habitats, often with finer substrates, than trout (Fig. 1) (KARLSTRØM, 1977 ; BAGLINIËRE and ARRIBE-MOUTOUNET, 1985) and further from the river banks, whereas brown trout parr are more abundant in the shallow and slowflowing streambank areas. In smaller streams, salmon parr tend to be restricted to intermediate depths $(15-40 \mathrm{~cm})$, while trout parr and older trout also occupy the deepest, pool-like areas. This depth distribution is a result of interactive spatial competition with brown trout. In the absence of brown trout, salmon use a wider depth range (LINDROTH, 1955 ; HEGGENES, 1990), but prefer the deeper stream areas (KENNEDY and STRANGE, 1986). They also increase in density in pools. Where other pool-dwelling species are abundant (cyprinids, percids), density of salmon parr in pools and slow water is reduced (BAGLINIERE and ARRIBE-MOUTOUNET, 1985). Thus, young Atlantic salmon are fundamentally tolerant with respect to water depths. However, the realized spatial niche is often restricted to a narrower range because of interference competition with brown trout, i.e. interactive segregation. In the absence of brown trout, young Atlantic salmon expand their spatial niche to also include relatively slow-deep estuarine and lacustrine habitats (HUTCHINGS, 1986 ; CUNJAK, 1992 ; PEPPER et al., 1992). This is presumably a response to reduced interspecific competition (GIBSON and COTE, 1982), and an example of different habitat selection caused by ecological release in allopatry (HEARN, 1987).

Habitat segregation in trout and salmon is often the combined effect of depth and velocity. Allopatric salmon may also colonize more slow-flowing stream areas (KARLSTRØM, 1977 ; KENNEDY and STRANGE, 1986 ; HEGGENES, 1990). The importance of higher water velocities in the distribution of sympatric Atlantic salmon, is therefore presumably the combined expression of morphological selection potential, i.e. salmon's greater tolerance towards higher water velocities because of the larger pectoral fins, and interference competition, i.e. dominance by the more aggressive trout (KALLEBERG, 1958) occupying the more slow-flowing areas.

Habitat selection in brown trout is less affected by interspecific competition, as brown trout is usually dominant over other salmonids (KALLEBERG, 1958 ; GATZ et al., 1987). It has been reported that brown trout in allopatry colonize more fast-flowing areas than when in sympatry with salmon (KARLSTRØM, 1977). The occasional presence of young trout in deep water, appears to be related to the presence of young salmon in the fast and shallow areas (BAGLINIËRE and ARRIBE-MOUTOUNET, 1985) or the absence of larger trout (below). 


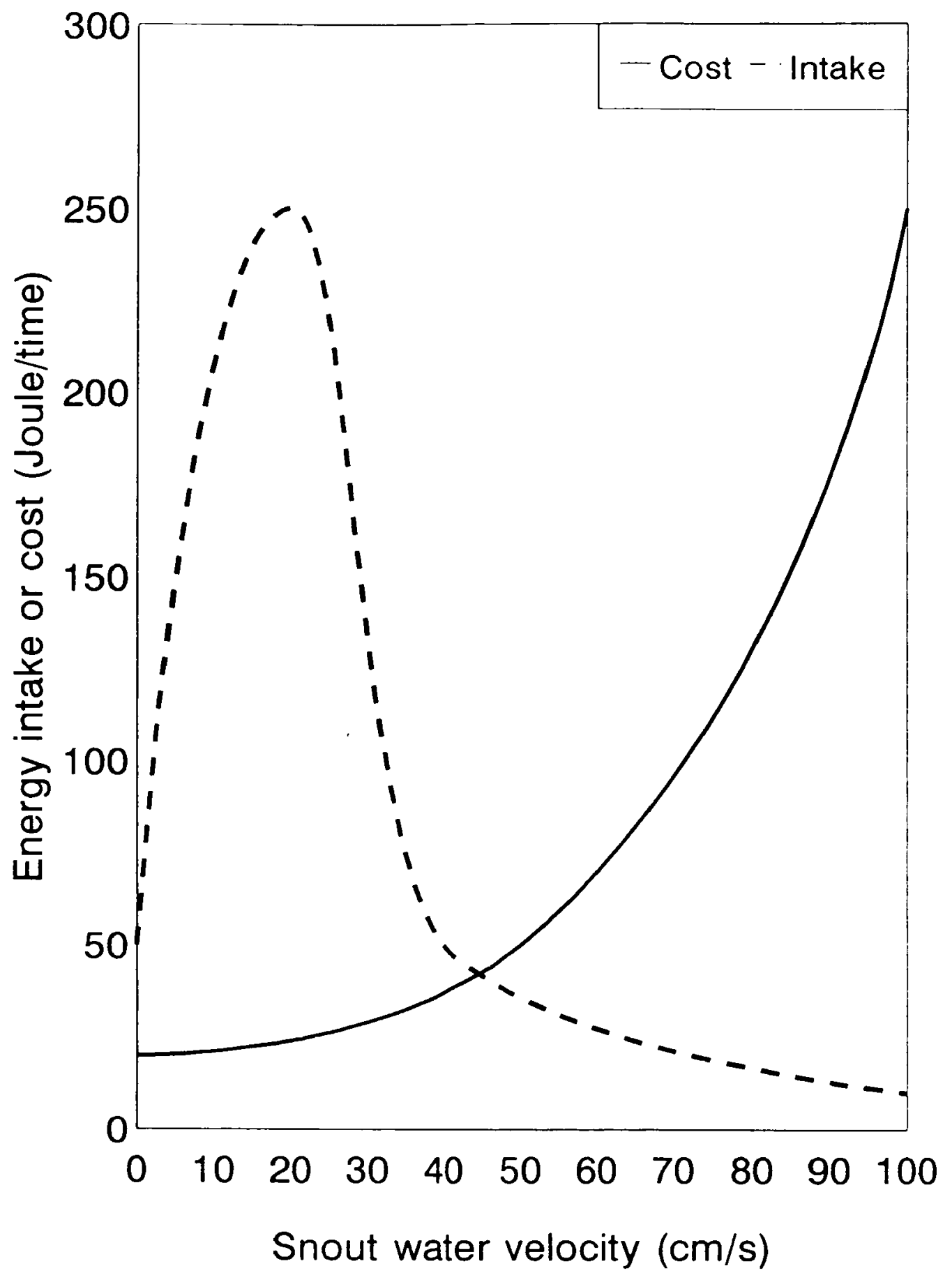

Figure 2 : Modèle de choix de microposition par des salmonidés se nourrissant sur la dérive, basé sur le gain énergétique net. Les truites et les saumons sélectionnent des microhabitats dans la colonne d'eau qui maximisent la différence entre les courbes de dépense et d'entrée d'énergie (nourriture), c'est-à-dire le gain énergétique net.

Figure 2 : Model for microposition choice by drift feeding stream salmonids based on net energy intake. Salmon and trout select water-column microhabitats that maximize the difference between the cost and energy (food) intake curves, i.e. net energy gain. 


\section{INTRASPECIFIC COMPETITIVE INTERACTIONS}

Intraspecific size or year-class competition may influence survival and growth (see GIBSON, 1993), and habitat selection in salmon parr (SYMONS and HELAND, 1978). Effects may vary, depending on population densities (HEGGENES and BORGSTRøM, 1991). Social interactions are evident. Dominant parr may be aggressive (SYMONS and HELAND, 1978) and the presence of large salmon or trout can depress feeding in salmon parr (STRADMAYER and THORPE, 1987 ; HUNTINGFORD et al., 1993). Such interactions may influence microposition choice by subordinate parr (KEENLEYSIDE and YAMAMOTO, 1962 ; GIBSON, 1988). Size-structured habitat selection, particularly for depth in brown trout (BOHLIN, 1977 ; HEGGENES unpubl.), is presumably an effect of intense intraspecific competition for space. Larger and dominant individuals colonize deep-slow habitats, while smaller and thus subordinate individuals are restricted to shallower more fast-flowing areas. Dominance is almost exclusively determined by size in both species (BACHMAN 1984, HUNTINGFORD et al., 1990), and there are indications that smaller trout occupy the deepslow areas in the absence of larger trout (BAGLINIËRE and CHAMPIGNEULLE, 1982).

Aggressiveness in both species is related to temperature, and is reduced at lower temperatures (FRASER et al., 1993 ; HEGGENES et al., 1993), and in salmon also with slow water flows (GIBSON, 1988). Aggressiveness is also related to density and food supply (KALLEBERG, 1958).

In conclusion, the fundamental micro-niche in both species is characterized by a narrow preference for low snout water velocities. It is, therefore, reasonably predictive. Selected mesohabitats are deep-slow in trout relative to salmon which are more tolerant towards high water velocities. Interference competition with trout results in spatial niche contraction in salmon.

\section{REFERENCES}

BACHMAN R.A., 1984. Foraging behavior of free-ranging wild and hatchery brown trout in a stream. Trans. Am. Fish. Soc., 113, 1-32.

BAGLINIĖRE J.L., CHAMPIGNEULLE A., 1982. Population density of brown trout (Salmo trutta) and Atlantic salmon (Salmo salar) juveniles on the river Scorff (Brittany) : Habitat selection and annual variation (1976-1989). Acta Oecol. (Oecol. Appl.), 3, 241-256.

BAGLINIĖRE J.L., ARRIBE-MOUTOUNET D., 1985. Micro-répartition des populations de truite commune (Salmo trutta L.) de juvénile de saumon atlantique (Salmo salar L.) et des autres espèces présentes dans la partie haute du Scorff (Bretagne). Hydrobiol., 120, 229-239.

BAGLINIĖRE J.L., THIBAULT M., DUMAS J., 1990. Réintroductions et soutiens de population du Saumon Atlantique (Salmo salar) en France. Rev. Ecol. (Terre et vie), Suppl. 5, 299-323.

BOHLIN T., 1977. Habitat selection and inter cohort competition of juvenile sea-trout (Salmo trutta). Oikos, 29, 112-117.

CHAPMAN D.W., 1966. Food and space as regulators of salmonid populations in streams. Am. Nat., 100, 345-357.

CUNJAK R.A., 1988. Behaviour and microhabitat of young Atlantic salmon (Salmo salar) during winter. Can. J. Fish. Aquat. Sci., 45, 2156-2160.

CUNJAK R.A., 1992. Comparative feeding, growth and movements of Atlantic salmon (Salmo salar) parr from riverine and estuarine environments. Ecol. Freshw. Fish, 1, 26-34.

FAUSCH K. D., 1984. Profitable stream positions for salmonids: relating specific growth rate to net energy gain. Can. J. Zool., 62, 441-451.

FRASER N., METCALFE N.B., THORPE J.E., 1993. Temperature-dependent switch between diurnal and nocturnal foraging in salmon. Proc. R. Soc. Lond. B 252, 135-139. 
FRASER N., HEGgENES J., METCALFE N.B., THORPE J.E., 1994. Cold summer temperatures cause juvenile Atlantic salmon, Salmo salar, to become nocturnal. Can. J. Zool., 73, 446-451.

GATZ A.J. Jr., SALE M.J., LOAR J.M., 1987. Habitat shifts in rainbow trout: competitive influences of brown trout. Oecologia, 74, 7-19.

GIBSON R.J., 1988. Mechanisms regulating species composition, population structure, and production of stream salmonids : a review. Pol. Arch. Hydrobiol., 35, 469-495.

GIBSON R.J., 1993. The Atlantic salmon in fresh water : spawning, rearing and production. Rev. Fish Biol. Fish., 3, 39-73.

GIBSON R.J., COTÉ Y., 1982. Production de saumoneaux et recaptures de saumons adultes étiquetés à la rivière Matamec, Côté Nord, Golfe du Saint-Laurent, Québec. Naturaliste Can., 109, 13-25.

HART P.J.B., 1993. Teleost foraging: facts and theories. In PITCHER T.J. (ed.), Behaviour of teleost fishes, 253-284. Chapman and Hall, Fish and Fisheries, series 7.

HEARN W.E., 1987. Interspecific competition and habitat segregation among streamdwelling trout and salmon : a review. Fisheries, 12, 24-31.

HEGGENES J., 1990. Comparisons of habitat availability and habitat use by an allopatric cohort of juvenile Atlantic salmon (Salmo salar) under conditions of low competition in a Norwegian stream. Holarc. Ecol., 14, 51-62.

HEGGENES J., SALTVEIT S. J., 1990. Seasonal and spatial microhabitat selection and segregation in young Atlantic salmon (Salmo salar L.) and brown trout ( $S$. trutta L.) in a Norwegian river. J. Fish Biol., 36, 707-720.

HEGGENES J., BORGSTRØM R., 1991. Effect of habitat types on survival, spatial distribution and production of an allopatric cohort of Atlantic salmon, Salmo salar, planted in a small stream. J. Fish Biol., 38, 267-280.

HEGGENES J., KROG O.M.W., LINDÅS O. R., DOKK J. G. and BREMNES T.,1993. Homeostatic behavioural responses in a changing environment: brown trout (Salmo trutta) become noctural during winter. J. Anim. Ecol., 62, 295-308.

HILL J., GROSSMAN G.D., 1993. An energetic model of microhabitat use for rainbow trout and rosyside dace. Ecology, 74, 685-698.

HUGHES N.F., DILL L.M., 1990. Position choice by drift-feeding salmonids : model and test for Arctic grayling (Thymallus arcticus) in subarctiv mountain streams, interior Alaska. Can. J. Fish. Aquat. Sci., 47, 2039-2048.

HUNTINGFORD F.A., METCALFE N.B., THORPE J.E., GRAHAM W.D., ADAMS C. E., 1990. Social dominance and body size in Atlantic salmon parr, Salmo salar L. J. Fish Biol., 36, 877-881.

HUNTINGFORD F.A., METCALFE N.B., THORPE J.E., 1993. Social status and feeding in Atlantic salmon, Salmo salar, parr : the effect of visual exposure to a dominant. Ethology, 94, 201-206.

HUTCHINGS J.A., 1986. Lakeward migrations by juvenile Atlantic salmon, Salmo salar. Can. J. Fish. Aquat. Sci., 43, 732-741.

JONES A.N., 1975. A preliminary study of fish segregation in salmon spawning streams. J. Fish Biol., 7, 95-204.

KALLEBERG $H$., 1958. Observations in a stream tank of territoriality and competition in juvenile salmon and trout (Salmo salar L. and S. trutta L.). Rep. Inst. Freshw. Res. Drottningholm, 39, 55-98.

KARLSTRØM Ö., 1977. Habitat selection and population densities of salmon (Salmo salarL.) and trout (Salmo trutta L.) parr in Swedish rivers with some references to human activities. Acta Universitatis Upsaliensis 404, $12 \mathrm{p}$. 
KEENLEYSIDE M.H.A., YAMAMOTO F.T., 1962. Territorial behaviour of juvenile Atlantic salmon (Salmo salar). Behaviour, 19, 139-169.

KENNEDY G.J.A., STRANGE C.D., 1986. The effects of intra and inter-specific competition on the distribution of stocked juvenile Atlantic salmon, Salmo salar, in relation to depth and gradient in an upland trout, Salmo trutta L., stream. J. Fish Biol., 29, 199-214.

LINDROTH A., 1955. Distribution, territorial behaviour and Smovements of sea trout fry in the River Indalsälven. Rep. Inst. Freshw. Res. Drottningholm, 36, 104-119.

MORANTZ D. L., SWEENEY R.K., SHIRVELL C.S., LONGARD D.A., 1987. Selection of microhabitat in summer by juvenile Atlantic salmon (Salmo salar). Can. J. Fish. Aquat. Sci., 44, 120-129.

PEPPER V.A., NICHOLLS T., OLIVER N.P., 1992. An evaluation of the quality of all fingerling Atlantic salmon (Salmo salar $L$.) released to natural lacustrine nursery areas in Newfoundland, Canada. Hydrobiol., 244, 249-259.

RINCON P. A., LOBON-CERVIA J., 1993. Microhabitat use by stream-resident brown trout: Bioenergetic consequences. Trans. Am. Fish. Soc., 122, 575-587.

STRADMAYER L., THORPE J.E., 1987. Feeding behaviour of wild Atlantic salmon, Salmo salar L., parr in mid- to late summer in a Scottish river. Aquacult. Fish. Mgmt., 18, 33-49.

SYMONS P.E.K., HELAND M., 1978. Stream habitats and behavioral interactions of underyearling and yearling Atlantic salmon (Salmo salar). J. Fish. Res. Board Can., 35, 175-183.

VANNOTE R.L., MINSHALL G.W., CUMMINS K.N., SEDELL J.R., CUSHING C.E., 1980. The river continuum concept. Can. J. Fish. Aquat. Sci., 37, 130-137. 